\title{
GEOCHEMICAL MODELING TO PREDICT THE CHEMISTRY OF LEACHATES FROM ALKALINE SOLID WASTES: OIL SHALE DEPOSITS, WESTERN U.S.A.
}

K.J. Reddy

James I. Drever

V.R. Hasfurther

1993

Journal Article

WWRC-93-03

In

Applied Geochemistry

\author{
K.J. Reddy \\ Wyoming Water Resources Center \\ James I. Drever \\ Geology and Geophysics Department \\ Victor R. Hasfurther \\ Civil Engineering Department \\ and \\ Wyoming Water Resources Center \\ University of Wyoming \\ Laramie, Wyoming
}




\title{
Geochemical modeling to predict the chemistry of leachates from alkaline solid wastes: oil shale deposits, western U.S.A.
}

\author{
K. J. REDDY \\ Water Resources Center, P.O. Box 3067, University of Wyoming, Laramie, WY 82071, U.S.A. \\ J. I. DREVER \\ Department of Geology \& Geophysics, P.O. Box 3006, University of Wyoming, Laramie, WY 82071, \\ U.S.A. \\ and \\ V. R. HASFURTHER \\ Civil Engineering and Water Resources Center, P.O. Box 3067, University of Wyoming, Laramie, \\ WY 82071, U.S.A.
}

\begin{abstract}
Oil shale processing at elevated temperatures to extract oil results in large amounts of alkaline oil shale solid wastes (OSSW). The objective of this study was to use a geochemical model to help predict the chemistry of leachates, including toxic chemicals, from OSSW. Several geochemical models were evaluated (e.g. EQ3/EQ6, GEOCHEM, MINTEQA2, PHREEQE, SOLMINEQ, WATEQFC); the model GEOCHEM was selected based on its more comprehensive capabilities. The OSSW samples were subjected to solubility and XRD studies. Element concentrations and $\mathrm{pH}$ of OSSW leachates were used as input to GEOCHEM to predict their chemistry. Ion activity products were used to infer the likely solid phases controlling the concentration of toxic elements (e.g. F and Mo) in these leachates. The model predicted that silicate phases produced during the heating process buffered the $\mathrm{pH}$ and controlled concentrations of major cations. The F concentrations in OSSW leachates appeared to be controlled by fluorite $\left(\mathrm{CaF}_{2}\right)$. Contrary to previous findings, powellite $\left(\mathrm{CaMoO}_{4}\right)$ probably does not control the concentrations of Mo in OSSW leachates.
\end{abstract}

\section{INTRODUCTION}

OIL SHALE deposits in the western U.S.A. contain mainly kerogen and carbonate minerals. Oil is recovered from the oil shale by thermally degrading the kerogen at elevated temperatures, which results in production of large amounts of oil shale solid wastes (OSSW). These OSSW are often alkaline (typical leachate $\mathrm{pH}$ may range from 10.0 to 13.0 ) and often contain elevated levels of toxic elements, particularly F and Mo (PARKer et al., 1977; Stollenwerk and RunNells, 1981; StARK and Redente, 1986; EssINGTON, 1990). One of the major environmental issues associated with the disposal of OSSW is prediction of the behavior of potentially toxic elements in the OSSW environments.

The behavior of various elements in OSSW environments is controlled by a number of chemical processes including the formation of soluble inorganic complexes and precipitation-dissolution reactions. Several geochemical models are available to predict the above chemical processes. However, each model differs in the environments to which it applies (Nordstrom et al., 1979). Thus, the objective of this study was to examine the applicability of existing geochemical models to predict the chemistry of leachates from OSSW.

\section{MATERIALS AND METHODS}

In order to evaluate the applicability of existing geochemical models for OSSW, the following criteria were established for preliminary screening of models:

1. Is the model in the public domain?

2 . Is the model well documented?

3. Is the model in use and being kept updated?

4. Is the model able to model processes of interest, or could it be readily modified to include such processes?

Having met the above criteria, the following six models were obtained and examined in detail:

1. EQ3/EQ6 (WolERY, 1979)

2. GEOCHEM (SPOSITO and MATTIGOD, 1980)

3. MINTEQA2 (FELMY et al., 1984)

4. PHREEQE (PARKHURST et al., 1980)

5. SOLMINEQ (KHARAKA et al., 1988)

6. WATEQFC (RUNNELLS and LINDBERG, 1981).

To examine the applicability of the above models to OSSW, laboratory experiments were conducted to generate the solubility data. Samples used in this study were PPP3 (Paraho Pilot Process), Lurgi and PPP6. A reference sample of the Green River Formation oil shale from the Piceance Creek Basin in Colorado was used in this study. The reference sample was processed at 770,1000 and $1295 \mathrm{~K}$ to produce PPP3, Lurgi and PPP6 OSSW, respectively. Samples were ground to pass a $0.25 \mathrm{~mm}$ sieve and used for solubility and XRD studies. Duplicate, $20 \mathrm{~g}$ samples were placed into $250 \mathrm{ml}$ Nalgene bottles with $100 \mathrm{ml}$ of distilleddeionized $\mathrm{H}_{2} \mathrm{O}$. Three drops of toluene were added to each bottle to suppress microbial activity. Each sample bottle was tightly capped, placed on a mechanical shaker, and 
Table 1. Capabilities of selected geochemical models

\begin{tabular}{|c|c|c|c|c|c|c|}
\hline Capability & EQ3/EQ6 & GEOCHEM & MINTEQA2 & PHREEQE & SOLMINEQ & WATEQFC \\
\hline Number of elements & 18 & 44 & 32 & 35 & 30 & 34 \\
\hline Number of species & 140 & 2000 & 373 & 296 & 340 & 500 \\
\hline Number of minerals & 250 & 500 & 238 & 374 & 220 & 375 \\
\hline Speciation/saturation & Yes & Yes & Yes & Yes & Yes & Yes \\
\hline Adsorption & No & Yes & Yes & No & Yes & No \\
\hline Ion exchange & No & Yes & No & No & Yes & No \\
\hline Organic complexation & No & Yes & No & No & Yes & No \\
\hline Mass transfer & Yes & No & No & Yes & Yes & No \\
\hline Temperature range, ${ }^{\circ} \mathrm{C}$ & $0-300$ & 25 & $0-300$ & - & $0-350$ & $0-100$ \\
\hline Pressure range, bars & $1-500$ & 1 & - & - & $1-1000$ & 1 \\
\hline \multicolumn{7}{|l|}{ Data base } \\
\hline Easily modified & Yes & Yes & Yes & Yes & No & Yes \\
\hline
\end{tabular}

reacted in an incubator at a constant temperature of $25^{\circ} \mathrm{C}$ (298K).

After 3 and $7 \mathrm{~d}$ reaction time, the sample suspensions were filtered through $0.45 \mu \mathrm{m}$ Millipore filters under an atmosphere of Ar gas to minimize uptake of atmospheric $\mathrm{CO}_{2}$ by OSSW leachates. Each filtered extract was divided into two subsamples. One subsample was acidified to between a pH of 5 and 6 with $\mathrm{HNO}_{3}$. The other subsample was left unacidified. The unacidified samples were analyzed immediately for $\mathrm{pH}$ and concentration of carbonate species. The acidified samples were analyzed for $\mathrm{Ca}, \mathrm{Mg}, \mathrm{Na}, \mathrm{K}, \mathrm{F}$, $\mathrm{Mo}, \mathrm{Cl}, \mathrm{SO}_{4}$, and $\mathrm{Si}$. The $\mathrm{pH}$ was measured with an Orion combination $\mathrm{pH}$ electrode. The $\mathrm{Ca}, \mathrm{Mg}, \mathrm{Si}$, and Mo concentrations were measured with inductively coupled plasma optical emission spectroscopy (ICP-OES). The Na and K concentrations were measured with atomic absorption (AA). The $\mathrm{F}$ and $\mathrm{C} 1$ concentrations were measured using Orion specific ion electrodes. For each measurement, electrodes were calibrated against known concentrations of $\mathrm{F}$ and $\mathrm{C} 1$ standard solutions provided by the Orion Company. The $\mathrm{F}$ and $\mathrm{Cl}$ concentrations in spent shale extracts were obtained by comparing the electrode values against standard values. The $\mathrm{SO}_{4}$ concentrations were measured by the $\mathrm{BaCl}_{2}$ precipitation method. The carbonate and bicarbonate concentrations were measured with the $\mathrm{CO}_{2}$ gas release method (REDDY et al., 1990a) to avoid interference by inorganic and organic anions. In this method, extracts were acidified to $\mathrm{pH} 4.50$ and evolved $\mathrm{CO}_{2}$ was trapped in a basic solution under an atmosphere of $\mathrm{Ar}$.

Element concentrations and $\mathrm{pH}$ of aqueous extracts were used as input to the selected geochemical model to calculate ion activities. From ion activities, ion activity products (IAPs) were calculated and compared with recently published solubility products $\left(K_{\mathrm{sp}} s\right.$ for interpretation of the chemistry of OSSW. It was assumed that IAPs within $\pm 0.50 \log$ units of $K_{\mathrm{sp}} s$ of solid phases represented equilibrium, and that the solid phase was a probable control on the concentrations of the ions involved. The differences within that range is accounted for the uncertainty of IAP and $K_{\text {sp }}$ measurements in the chemical literature (STUMM and MORGAN, 1981). The XRD analysis of samples was performed on randomly oriented samples with a Scintag PAD V powder diffractometer using Ni-filtered $\mathrm{CuK} \alpha$ radiation.

\section{RESULTS AND DISCUSSION}

Table 1 summarizes the general features of the models, such as total number of elements, aqueous species and solid phases, and the temperature and pressure ranges over which calculations can be made. GEOCHEM, MINTEQA2, SOLMINEQ and
WATEQFC are speciation and saturation models; EQ3/EQ6 and PHREEQE are mass transfer as well as saturation models. Significant differences were found in the thermodynamic databases. All of the models lacked data for certain solid phases and solution species, which are expected to be significant in OSSW environments.

Based on the model evaluation, GEOCHEM was selected for inputting new or altered values into its database because it not only computes the highest number of elements (44), solution species (2000) and solid phases (500) but the thermodynamic database is the easiest to update. Updated association constants and solubility constants for different solution species and solid phases were (REDDY et al., 1990b) included in the GEOCHEM database. For example, association constants for $\mathrm{H}_{2} \mathrm{SiO}_{4}^{2-}, \mathrm{HSiO}_{4}^{3-}, \mathrm{SiO}_{4}^{4-}$, $\mathrm{CaH}_{3} \mathrm{SiO}_{4}^{+}, \quad \mathrm{Ca}\left(\mathrm{H}_{3} \mathrm{SiO}_{4}^{-}\right)_{2}^{0}, \quad \mathrm{MgH}_{3} \mathrm{SiO}_{4}^{+}, \quad \mathrm{Mg}-$ $\left(\mathrm{H}_{3} \mathrm{SiO}_{4}^{-}\right)_{2}^{0}, \mathrm{MoO}_{4}^{0}, \mathrm{HMoO}_{4}^{-}, \mathrm{CaMoO}_{4}^{0}, \mathrm{NaMoO}_{4}^{-}$, $\mathrm{KMoO}_{4}^{-}, \mathrm{CaF}^{+}, \mathrm{MgF}^{+}, \mathrm{NaF}^{0}, \mathrm{KF}^{0}, \mathrm{CaSO}_{4}^{0}, \mathrm{MgSO}_{4}^{0}$, $\mathrm{NaSO}_{4}^{-}$, and $\mathrm{KSO}_{4}^{-}$and solubility constants for wollastonite $\left(\mathrm{CaSiO}_{3}\right)$, diopside $\left(\mathrm{CaMg}\left(\mathrm{SiO}_{3}\right)_{2}\right)$, monticellite $\left(\mathrm{CaMgSiO}_{4}\right)$, akermanite $\left(\mathrm{Ca}_{2} \mathrm{MgSi}_{2} \mathrm{O}_{7}\right)$, merwinite $\left(\mathrm{Ca}_{3} \mathrm{MgSi}_{2} \mathrm{O}_{6}\right)$, calcite $\left(\mathrm{CaCO}_{3}\right)$, powellite, $\left(\mathrm{CaMoO}_{4}\right)$, and fluorite $\left(\mathrm{CaF}_{2}\right)$ were included. The chemical analyses of raw and spent shale leachates are summarized in Table 2 . The complete

Table 2. Chemical data of raw and OSSW leachates for a 7-d reaction period $(-\log \mathrm{mol} / \mathrm{l}$; concentration mean of duplicates)

\begin{tabular}{lcrrr}
\hline & Raw shale & PPP3 & Lurgi & PPP6 \\
\hline $\mathrm{pH}$ & 8.21 & 10.68 & 12.07 & 12.10 \\
$\mathrm{Ca}$ & 2.46 & 3.72 & 2.35 & 2.90 \\
$\mathrm{Mg}$ & 2.66 & 5.00 & 5.03 & 5.06 \\
$\mathrm{Na}$ & 2.47 & 0.89 & 2.48 & 1.14 \\
$\mathrm{~K}$ & 3.50 & 3.09 & 2.98 & 2.18 \\
$\mathrm{Si}$ & 3.46 & 4.56 & 3.86 & 3.21 \\
$\mathrm{SO}_{4}$ & 2.39 & 1.76 & 2.75 & 1.95 \\
$\mathrm{C}^{*}$ & 2.73 & 2.22 & 4.48 & 4.24 \\
$\mathrm{Cl}$ & 3.77 & 1.30 & 3.30 & 1.70 \\
$\mathrm{~F}$ & 3.70 & 2.87 & 3.57 & 3.70 \\
$\mathrm{Mo}$ & 5.20 & 4.75 & 5.03 & 4.57 \\
\hline
\end{tabular}

*Inorganic carbonate and bicarbonate species. 
Table 3. Potential solid phases controlling the solubilities of $\mathrm{Ca}, \mathrm{Mg}, \mathrm{F}$ and $\mathrm{Mo}$ in OSSW leachates (mean of duplicates)

\begin{tabular}{|c|c|c|c|c|}
\hline \multirow[b]{2}{*}{ Solid phase } & \multicolumn{4}{|c|}{ Saturation Index $\left(\log\right.$ IAP $\left./ K_{\mathrm{sp}}\right)$} \\
\hline & $\log K_{\mathrm{sp}}$ & PPP3 & Lurgi & PPP6 \\
\hline $\mathrm{Ca}(\mathrm{OH})_{2}$ (portlandite) & 23.02 & -6.32 & -1.76 & -2.27 \\
\hline $\mathrm{CaSiO}_{3}$ (wollastonite) & 13.27 & -2.46 & 0.03 & -0.33 \\
\hline $\mathrm{Ca}_{2} \mathrm{MgSi}_{2} \mathrm{O}_{7}$ (akermanite) & 46.10 & -8.98 & -1.79 & -1.88 \\
\hline $\mathrm{CaMg}\left(\mathrm{SiO}_{3}\right)_{2}$ (diopside) & 21.60 & -1.18 & 1.45 & 1.87 \\
\hline $\mathrm{Mg}(\mathrm{OH})_{2}$ (brucite) & 16.84 & -1.32 & 1.19 & 1.52 \\
\hline $\mathrm{MgSiO}_{3}$ (clinoenstatite) & 11.42 & -1.79 & -1.51 & -0.9 \\
\hline $\mathrm{Mg}_{2} \mathrm{SiO}_{4}$ (forsterite) & 28.87 & -3.72 & -0.93 & -0.17 \\
\hline $\mathrm{Mg}_{3} \mathrm{Si}_{4} \mathrm{O}_{10}(\mathrm{OH})_{2}$ (talc) & 22.26 & 0.44 & 0.14 & 1.54 \\
\hline $\mathrm{CaSO}_{4} \cdot 2 \mathrm{H}_{2} \mathrm{O}$ (gypsum) & -4.64 & -2.26 & -1.81 & -1.29 \\
\hline $\mathrm{CaMg}\left(\mathrm{CO}_{3}\right)_{2}$ (dolomite) & -17.85 & 2.05 & -1.14 & -0.94 \\
\hline $\mathrm{CaF}_{2}$ (fluorite) & -10.41 & -0.09 & 0.41 & -0.39 \\
\hline $\mathrm{CaMoO}_{4}$ (powellite) & -8.05 & -2.13 & -0.32 & -0.85 \\
\hline
\end{tabular}

results of the chemical data are reported in REDDY et al. (1990b). The data from the $7 \mathrm{~d}$ reaction period only is used here because it provided the most uniform results.

Processing of raw shale at high temperatures caused a general increase in $\mathrm{pH}, \mathrm{F}$ and $\mathrm{Mo}$ and a decrease in $\mathrm{Ca}, \mathrm{Mg}, \mathrm{Si}$ and $\mathrm{C}$ in OSSW leachates. Potential solubility controls on $\mathrm{Ca}, \mathrm{Mg}, \mathrm{F}$ and $\mathrm{Mo}$ in leachates from OSSW samples are presented in Table 3. A complete list of saturation indices for different minerals is reported in REDDY et al. (1990b), and only a few minerals relevant to the results are discussed here. For the PPP3 sample, the IAPs show that calcite and talc are close to saturation, suggesting that the $\mathrm{Ca}$ and $\mathrm{Mg}$ concentrations are probably controlled by calcite and talc, respectively. The IAPs for the PPP6 and Lurgi samples show that wollastonite, forsterite and talc are close to saturation, suggesting that silicate phases formed during high-temperature processing are probably controlling the solubilities of $\mathrm{Ca}$ and $\mathrm{Mg}$ in the leachates.

Major minerals identified by the XRD analysis are listed in Table 4. Processing raw shale at elevated temperatures causes decomposition of carbonate phases (e.g. calcite, dolomite) and production of oxide phases (e.g. periclase) and silicate phases (e.g. akermanite, diopside). Several other studies have reported similar results (PARK et al., 1979; Essington et al. 1987; MAson et al., 1984). Oxide phases are generally more soluble than silicate phases, and often dissolve upon contact with moisture. The IAPs of oxide phases in spent shale leachates indicated a high degree of undersaturation. Thus, silicate phases produced during the process of heating appear to buffer the $\mathrm{pH}$ and control $\mathrm{Ca}$ and $\mathrm{Mg}$ solubilities in the leachates. However, carbonates in the PPP3 sample, which was produced by processing raw shale at a moderate temperature, did not decompose completely, and calcite was still buffering the $\mathrm{pH}$ and controlling the solubility of $\mathrm{Ca}$ in leachates.

Several studies (Stollenwerk and RunNells, 1981; REDDY and HASFURTHER, 1989; EssINGTON et al., 1987) have reported that fluorite and powellite probably control the solubilities of $F$ and $M o$ in OSSW leachates, respectively. However, the IAPs in this study show a close approach to saturation with respect to fluorite and a high degree of undersaturation with respect to powellite, except for the Lurgi sample. These results suggest that fluorite may be controlling the solubility of $F$, and that powellite does not control the solubility of Mo in OSSW leachates.

\section{CONCLUSIONS}

Evaluation of the geochemical models EQ3/EQ6, GEOCHEM, MINTEQA2, PHREEQE, SOLMINEQ and WATEQFC suggested that these models lack thermodynamic data for solid phases and solution species that are important for OSSW environments. GEOCHEM was selected and modified with updated thermodynamic data for different solution

Table 4. Major minerals identified in raw shale and OSSW samples (processing temperature, $\mathrm{K}$, in parenthesis)

\begin{tabular}{|c|c|c|c|}
\hline Raw shale & $\begin{array}{l}\text { PPP3 } \\
(770)\end{array}$ & $\begin{array}{l}\text { Lurgi } \\
(1000)\end{array}$ & $\begin{array}{c}\text { PPP6 } \\
(1295)\end{array}$ \\
\hline $\begin{array}{l}\text { Dolomite } \\
\text { Quartz } \\
\text { Calcite } \\
\text { Analcime } \\
\text { K-feldspar }\end{array}$ & $\begin{array}{l}\text { Dolomite } \\
\text { Quartz } \\
\text { Calcite } \\
\text { Akermanite } \\
\text { K-feldspar }\end{array}$ & $\begin{array}{l}\text { Quartz } \\
\text { Calcite } \\
\text { Wollastonite } \\
\text { K-feldspar } \\
\text { Periclase }\end{array}$ & $\begin{array}{l}\text { K-feldspar } \\
\text { Quartz } \\
\text { Calcite } \\
\text { Periclase } \\
\text { Diopside }\end{array}$ \\
\hline
\end{tabular}


species and solid phases to predict the chemistry of leachates from OSSW. The model indicated that silicate phases including wollastonite and forsterite, produced during the heating process, probably buffer the $\mathrm{pH}$ and control $\mathrm{Ca}$ and $\mathrm{Mg}$ concentrations. Fluoride concentrations suggested a close approach to saturation with respect to fluorite. The Mo concentrations were highly undersaturated with respect to powellite.

Acknowledgement-The authors express thanks to the United States Department of Energy and the Western Research Institute for funding this work under co-operative agreement No. DE-FC21-86M11076.

Editorial handling: Brian Hitchon.

\section{REFERENCES}

Essington M. E. (1990) Calcium molybdate solubility in spent oil shale and a preliminary evaluation of the association constants for the formation of $\mathrm{CaMoO}_{4}^{0}$ (aq), $\mathrm{KMoO}_{4}^{-}(\mathrm{aq})$, and $\mathrm{NaMoO}_{4}^{-}(\mathrm{aq})$. Environ. Sci. Tech. 24, 214-220.

Essington M. E., Spackman L. K., Harbour J. D. and Hartman K. D. (1987) Physical and chemical characteristics of restored and combusted western reference oil shale. U.S. Deparment of Energy. Report DE-FC2186ME1111076.

Felmy A. R., Girvin D. and Jenne E. A. (1984) MINTEQA2: a computer program for calculating aqueous geochemical equilibria. U.S. Environmental Protection Agency, Washington, D.C.

Kharaka Y. K., Gunter W. D., Aggarwal P. K., Perkins E. H. and De BraAl J. D. (1988) SOLMINEQ.88: a computer program for geochemical modeling of waterrock interactions. U.S. Geol. Surv. Water. Resour. Invest. 88-4227.

Mason G. M., Spackman L. K. and Williams J. D. (1984) High temperature minerals in an in situ oil shale retort. 17th Oil Shale Symposium Proceedings, Colorado School of Mines.

Nordstrom D. K. et al. (1979) A comparison of computerized chemical models for equilibrium calculations in aqueous systems. In Chemical Modeling in Aqueous Systems (ed. E. A. JENNE), Vol. 93, pp. 857-892.

Park W. C., Lindemorris A. E. and TABB G. A. (1979) Chemical changes during oil shale retorting. In situ 3, 353-381.

Parker H. W., Bethea R. A., Gruven N., Grazdor M. N. and WATTA J. C. (1977) Interactions between groundwater and in-situ retorted oil shale. 2nd Pacific Engineering Congress Proc. 1, 450-454.

Parkhurst D. L., Thorstenson D. C. and Plummer L. N. (1980) PHREEQE. U.S. Geol. Surv. Water Resour. Invest. 80-96.

REDDY K. J., LindSAY W. L., WORKMAN S. M., and DREVER J. I. (1990a) Measurement of calcite ion activity products in soil. Soil Sci. Soc. Am. J. 54, 67-71.

Reddy K. J., DReVer J. I. and Hasfurther V. R. (1990b) Application of geochemical model to the prediction of the chemistry of extracts from non-recarbonated and recarbonated spent shales. U.S. Department of Energy. Rept. DE-FC-21-86M11076.

RuNNELls D. D. and LiNDBERg R. D. (1981) WATEQFC: hydrogeochemical exploration for uranium ore deposits: use of the Computer Model. J. geochem. Explor. 15, 3750.

SPostro G. and MATtigod M. V. (1980) GEOCHEM: a computer program for the calculation of chemical equilibria in soil solutions and other natural water systems. The Kearney Foundation of Soil Science, University of California, Riverside.

Stark J. K. and Redente E. F. (1986) Trace elements and salt movement in retorted oil shale disposal sites. $J$. Environ. Qual. 15, 282-288.

Stollenwerk K. G. and Runnells D. D. (1981) Composition of leachates from surface retorted and unretorted Colorado oil shales. Environ. Sci. Tech. 15, 1340-1346.

StUmm W. and Morgan J. J. (1981) Aquatic chemistry. Wiley-Interscience, New York.

WOLERY T. J. (1979) EQ3/EQ6: calculation of chemical equilibria between aqueous solution and minerals. Lawrence Livermore Laboratory, Livermore, CA, Rept. UCR-52658. 